\title{
İngilizce Öğretmeni Adaylarının FATİH Projesine Yönelik Öz-Yeterlikleri*
}

\author{
Muhammed AKINCI ${ }^{1}$ \\ 1 Arş.Gör., Akdeniz Üniversitesi, Ë̈itim Fakültesi, mubammed.akno@gmail.com
}

Geliş Tarihi/Received: 30.11.2016 Kabul Tarihi/Accepted: 10.5.2017 e-Yayım/e-Printed: 4.7.2017

DOI: http://dx.doi.org/10.14582/DUZGEF.1802

\begin{abstract}
ÖZ
Bu çalı̧̧ada Eğitim Fakültesi, İngilizce Öğretmenliği bölümünde öğrenim gören öğretmen adaylarının FATíH Projesi teknolojilerini kullanmaya yönelik öz-yeterlik inançlarının belirlenmesi amaçlanmıștır. Araştırmada karma araştırma desenlerinden Eşzamanlı Desen kullanılmıştır. Araş̧ırmada Akdeniz Üniversitesi, Eğitim Fakültesi, İngilizce Öğretmenliği bölümünde 296 öğrenciden "FATiH Projesi Teknolojileri Öz-Yeterlike Ölecĕğ" aracillğıyla toplanmıştır. Nitel veriler ise doküman incelemesi ve görüşme tekniğiyle toplanmıştır. Toplanan ölçek verileri çeşitli parametrik testler ile analiz edilmiştir. Doküman incelemesi ile toplanan veriler "Var veya Yok" tekniği ile analiz edilmiş, görüşmelerden elde edilen veriler ise kodlanarak temalar halinde analiz edilmiştir. Verilerin analizi sonucunda çalışma grubunda yer alan bireylerin FATİH Projesi teknolojilerini kullanmaya yönelik öz-yeterlik inançlarının yüksek düzeyde olduğu ortaya çıkmıştır. Ayrıca İngilizce öğretmeni adaylarının öz-yeterlik inançları sınıfa göre anlamlı bir farklılık göstermezken, cinsiyete göre erkekler lehine anlamlı farklılık göstermektedir. Doküman incelemesinden elde edilen bulgulara göre YÖK tarafından İngilizce Öğretmenliği Lisans Programında belirlenen derslerin içerikleri MEB’in İngilizce Öğretmenlerinden beklediği FATİH Projesi teknolojilerinin kullanımına yönelik yeterlikleri \%92,85 karşılamaya olanak tanımaktadır. Ayrıca görüşme bulguları öğretmen adaylarının FATİH Projesi hakkında genel düzeyde bilgi sahibi olduklarını, fakat bu bilgilerin büyük oranda rastgele edinilen bilgiler olduğunu ama proje hakkında olumlu düşüncelere sahip olduklarını göstermektedir. Daha üst düzeyde yeterliklerin kazanımı için proje hedefleri ve program çıktıları eşleştirilerek daha somut ve uygulanabilir öğretim etkinlikleri geliştirilebilir.
\end{abstract}

Anahtar Kelimeler: FATİH Projesi, İngilizce öğretmeni adayı, öz-yeterlik

\section{English Teacher Candidates' Self-Efficacy towards FATIH Project}

\begin{abstract}
The aim of this study is to determine teacher candidates' self-efficacy beliefs towards the usage of FATIH Project technologies who study in Faculty of Education, English Language Teaching Department. In the study Convergent Parallel Design was used which is one of the mixed research designs. The quantitative data of the study was collected through "FATIH Project Technologies Self-Efficacy Scale" from 296 undergraduate students who study in Akdeniz University, Faculty of Education, English Language Teaching Department. The qualitative data was also collected through document analysis and interviews. The scale data was analysed some parametric tests. Furthermore, the research data collected through document analysis was analysed through "Yes or No" technique and the data obtained from the interviews was analysed as themes after coding. The results of the data analysis show that participants in the study group have high level of self-efficacy beliefs towards the usage of FATIH Project technologies. While teacher candidates' self-efficacy beliefs towards the usage of FATIH Project technologies do not significantly differ according to class, their beliefs significantly differ according to gender in favour of male participants. According to findings gathered from document analysis the course contents prepared by HEC \%92,85 allow the teacher qualifications designated by MONE in this context. Moreover interview findings show that teacher candidates have general knowledge about FATIH Project. This knowledge is randomly acquired however they have positive ideas about the project. For a higher level of proficiency, more concrete and feasible teaching activities can be developed by matching the project objectives and program outcomes.
\end{abstract}

Keywords: FATIH Project, English teacher candidate, self-efficacy

\section{GİRİ̧}

Günümüzde bilişim teknolojileri insanların ceplerinde taşıyabildiği boyutlardadır ve onlara ellerini uzattıklarında ulaşabilecekleri kadar yakın hale gelmiştir. İnsanlara böylesine yakın olan bilişim teknolojileri

\footnotetext{
*İngilizce Öğretmeni Adaylarının FATİH Projesine Yönelik Öz-Yeterlikleri isimli yüksek lisans tezinin makaleleştirilmiş halidir.
} 
eğitim ortamları için kaçınılmaz olmuştur. Duffy ve McDonald (2011), eğitim teknolojilerinin hem öğrenci, hem de öğretmen için öğretimsel deneyimleri genişlettiğini ve zenginleştirdiğini ifade etmiştir. Ayrıca bilişim teknolojileri bir yandan bireysel öğrenmeyi güçlendirirken bir yandan da bireyler arasında bağlantı kurmay1 sağlayarak sosyal öğrenmeyi geliştirir. Bu bağlamda teknoloji, hem öğrencilere hem de eğitimcilere yeni firsatlar sunar (Perkmen ve Tezci, 2011). Bu amaçla ülkemizde de çeşitli çalışmalar ve projeler ortaya koyulmaktadır. Fırsatları Artırma ve Teknolojiyi İyileştirme Hareketi (FATİH) Projesi de bunlardan biridir.

Eğitim teknolojilerinin yabancı dil öğretiminde de faydalarının olduğu iddia edilmektedir (Tomakin ve Yeşilyurt 2013; Kayak ve Kır, 2015). Ülkemizde yabancı dil öğretimi de dâhil devlet okullarında bu teknolojileri de kullanarak eğitim verebilecek kişiler ise öğretmenlerdir. Konu bu bağlamda ele alındığında FATİH Projesi ile ilgili öğretmen yeterlilikleri, bu yeterlikleri kazandıracak değişkenlerin durumu ve öğretmen adaylarının projenin getirmiş olduğu teknolojileri kullanma konusundaki öz-yeterlikleri projenin sağılılı bir şekilde yürütülmesi açısından önemlidir. Özellikle araştırmaya konu olan İngilizce Öğretmenliği ders içeriklerinin FATİH Projesi öğretmen yeterliklerini ne ölçüde karşıladığı da üzerinde dikkatle durulması gereken bir konudur. Çünkü bu programlarda öğrenim gören ve ileride FATİH Projesinin uygulamalarını gerçekleştirecek olan öğretmen adaylarının projenin getirmiş olduğu teknolojileri kullanma konusunda kendilerini yeterli görüp görmedikleri, bu durum hakkındaki görüş ve düşünceleri yine bu programların içerikleriyle doğrudan ilişkilidir.

Ülkemizde YÖK’e bağlı olan eğitim fakülteleri ve MEB vb. kurumların yaptıkları çalışmaları koordineli bir biçimde yürütüp yürütmedikleri tartsşmaya açık bir konudur. Örnek olarak YÖK tarafindan belirlenen eğitim fakültesi ders kurlar1 2006-2007 akademik yllından bu yana güncellenmemiştir (YÖK, 2007). Fakat FATİH Projesi 2013 yılı itibariyle uygulanması planlanmış bir projedir (MEB, 2012). Sadece bu durum MEB'in yapmış olduğu projelerle YÖK'ün çalışmalarının uyumunun sorgulaması için bir sebep olarak görülebilir. Ayrıca öğretmenlerin yapacakları uygulama becerisini nasıl edindikleri ve bu bağlamada kendilerini yeterli görüp görmedikleri akla gelen başlıca durumlardandır.

Öğretmenlerin ve öğretmen adaylarının kendi yeterliklerini değerlendirme durumu ise öz-yeterlik kavramıyla açıklanabilir. Schunk ve Zimmerman (2007) bu bağlamda öz-yeterlik inançları yüksek bireylerin diğer bireylerle kıyaslandığında bir beceriyi edinmede ya da bir görevi yerine getirmede hazırbulunuşluklarının daha yüksek olduğunu, daha çok çalıştıklarını ve zorluklara karşı daha uzun süre direnç gösterdiklerini ifade etmiştir. Ayrıca yapılan araştırmalar öz-yeterlik inanıcının akademik motivasyonu, öğrenme ve başarıyı etkilediğini göstermektedir (Pajares, 1996; Schunk, 1995). Bu sebeplerden dolayı İngilizce öğretmeni adaylarının FATİH Projesine yönelik “öz-yeterlikleri” bir araştırma konusu olarak belirlenmiştir.

\section{1. Öğgretmenlik Mesleği ve Öz-Yeterlik İnancı}

Bandura (1977) öz-yeterlik kavramını ilk defa Sosyal Öğrenme Kuramı bağlamında ortaya atmıştır. Özyeterlik bir bireyin alışılmamıs, kestirilemez ve muhtemelen baskıcı öğeler içeren durumlarda en iyi şekilde organize davranışlar göstermesiyle ilgili kendini yargılama durumunu ifade eder (Bandura, 1977, 1982). Bandura (1986)'da öz-yeterliğge yeni bir boyut getirmiştir: algılanan öz yeterlik olarak ifade edilen bu boyut kişilerin istenen biçimde ve gereken düzeyde eylemler ortaya koymalarına yönelik kendilerini yargılamasıdır. Ayrıca bu görüşe göre bireyler düşünceleri, hisleri ve davranışları üzerinde hâkimiyet sağlamalarına yarayan inançlara sahiptir. Bandura (1988)'ya göre insanların çoğu zaman bir konuyla ilgili nasıl davranacakları onların yeterlikleriyle ilgili sahip oldukları inançlar sayesinde tahmin edilebilir ve bu inançlar öz-yeterlik inancı olarak ifade edilmektedir. Ayrıca öz- yeterlik inancı bireylerin düşünme şekillerini ve duygusal tepkilerini de etkiler (Pajares, 1996). Bir başka deyişle bireylerin algılanan öz-yeterliklerine karşı duydukları inanç öz-yeterlik inancı olarak ifade edilebilir.

Öz-yeterlik inancı kavramı ortaya atıldığından bu yana çeşitli bağlamalarda farklı disiplinler tarafından kullanılagelmiştir ve bu kavram eğitim araştırmalarında da önemli bir yer tutmaktadır (Pajares, 1997). Eğitimde öz-yeterlik inançlarıyla ilgili bulgulara ulaşılan dikkat çeken bir alan ise öğretmenlerin öz-yeterlik inançlarıyla ilgilidir. Bu bağlamda öğretmen öz-yeterliği çeşitli şekillerde tanımlanmaya çalışılmıştır. Öğretmen özyeterliğiyle ilgili en genel ifade öğrencinin başarılı çıtılar ortaya koyabilmesini etkileme inancıdır (Soodak ve 
Podell, 1996). Bir başka tanıma göre de öğretmenlerin öğrencilerini hangi düzeyde olumlu anlamda etkileyebileceklerine yönelik inançları öğretmen öz-yeterlik inancı olarak tanımlanmaktadır (Riggs ve Enochs 1990). Sosyal Bilişsel Kuram öğretmen öz-yeterliğinin muhtemel kaynaklarına genel bir rehberlik görevi yapmaktadır (Tschannen-Moran ve Hoy, 2007). Bireyler öz-yeterlik inançlarını dört farklı kaynaktan elde ettikleri bilgilerle oluştururlar. Bunlar:

$\checkmark$ Tam ve doğru deneyimler,

$\checkmark$ Sosyal modeller,

$\checkmark$ Sözel ikna,

$\checkmark$ Fizyolojik ve duygusal durumlardır (Bandura, 1988).

Öğretmenlerin öz-yeterlik inancının yüksek olması onlara eğitim öğretim faaliyetleri adına büyük katkılar sağlayabilir. Öz-yeterlik inanıcı yüksek öğretmenler öğrencilerinin motivasyonu düşük olsa ve öğrenme güçlüğü yaşasalar dahi onları teşvik etmede başarılı adımlar atıp daha çok çalısıır ve daha uzun süre mukavemet gösterirler. Çünkü onlar kendilerine ve öğrencilerine inanırlar (Tschannen-Moran ve Woolfolk Hoy, 2001). Çünkü öğretmen öz-yeterliği öğrenci motivasyonu ve başarısında belirleyici etkiye sahiptir (Midgley, Feldlaufer ve Eccles, 1989; Ross, 1992). Elbette ki öğretmen öz-yeterlik inancının yüksek olması bir artıyken düşük olması da çeşitli sorunlara sebep olabilir. Bunun en belirgin örneği Friedman ve Farber (1992)'in de ifade ettiği gibi öz-yeterlik inanıcı düşük öğretmenlerin mesleki tükenmişliklerinin daha yüksek olmasıdır. Bu durum öğretmenlerin mesleklerinin gereği olan faaliyetleri yerine getirmede onlara büyük bir sorun teşkil edebilir.

Öğretmen öz-yeterlik inancını teknolojiden ve teknolojinin getirmiş olduğu değişim ve gelişimden bağımsız olarak düşünmemek gerekir. Bandura (1988) teknolojik gelişmelerin öz-yeterlik inancına karşı sahip olunan eski bariyerlerin tekrar ortaya çıkmasına sebep olabileceğini ve bu durumun tedavi edilmesi gereken bir sorun olduğunu ifade etmiştir. Bir başka deyişle öğretmenler teknolojik gelişmelere ayak uyduramadıkları takdirde meslekleriyle ilgili öz-yeterlik inançlarını kaybedebilirler. Teknolojik gelişmeler öğretmenlerin özyeterlik inançlarını etkilediği gibi öğretmenlerin öz-yeterlik inançları da değişim ve gelişime uyum sağlamayı etkileyebilir. Çünkü öğretmenlerin öz-yeterlik inancı yenilik ve değişime yönelik öğretmen tutumunu etkilemektedir (Fuchs, L. S., Fuchs, D. ve Bishop, 1992).

Öz-yeterlik inançlarını bireylerin ya da öğretmen adaylarının hizmet öncesi almış oldukları eğitiminin niteliği ile yakından ilgili olduğunu da söylemek mümkündür. Bu durum eğitim teknolojilerine yönelik hizmet öncesi eğitimin öğretmen adaylarının öğretmenlik mesleğini gerçekleştirirken bu bağlamda sahip olacakları özyeterlik inançları adına önemlidir. Kinzie ve Delcourt (1991); Wang, Ertmer ve Newby (2004), yapmış oldukları araştırmalarda öğretmen eğitiminde bilgisayar kullanımına yönelik gerçek deneyimlerin gerek derste olsun gerekse günlük kullanımlarda tutum ve öz-yeterliğin güçlü bir belirleyicisi olduğunu ifade etmişlerdir. Bu sebeple FATİH Projesi gibi projelerin bilgi alt yapısının öğretmenlere ve öğretmen adaylarına kazandırılmasının hiç şüphesiz onlara mesleklerinin gerektirdiği uygulamaları gerçekleştirmede önemli bir yeri olan öz-yeterlik inançlarını geliştirme adına katkıda bulunacağı unutulmamalıdır. Bu sebeple araştırmadan elde edilecek bulgular ile İngilizce öğretmeni adaylarının FATİH Projesi teknolojilerini kullanmaya yönelik özyeterlik inançları, bu inançları kazandırmada programların durumu ve FATİH Projesi ve öğrenim gördükleri program hakkında görüşleri ortaya koyulduğundan yükseköğretim boyutunda yapılabilecek uygulamalara fayda sağlama adına yapılan çalışma önemlidir.

\section{ARAŞTIRMANIN AMACI}

Bu çalışmada yabancı dil öğretiminde teknoloji kullanımından yola çıkarak Eğitim Fakültesi, İngilizce Öğretmenliği bölümünde öğrenim gören öğretmen adaylarının FATİH Projesi teknolojilerini kullanmaya yönelik öz-yeterlik inançlarının belirlenmesi amaçlanmışırı. Bu genel amaca uygun olarak araştırmada aşağıdaki sorulara cevap aranmıştır:

$\checkmark$ İngilizce öğretmeni adaylarının FATİH Projesi kapsamında internet ve bilgisayar teknolojilerini kullanmaya yönelik öz-yeterlik inançları ne düzeydedir? 
$\checkmark$ İngilizce öğretmeni adaylarının FATİH Projesi kapsamında internet ve bilgisayar teknolojilerini kullanmaya yönelik öz-yeterlik inançları sınıfa (1, 2, 3 ve 4. Sınıf) göre anlamlı bir farklılık göstermekte midir?

$\checkmark$ İngilizce öğretmeni adaylarının FATİH Projesi kapsamında internet ve bilgisayar teknolojilerini kullanmaya yönelik öz-yeterlik inançları cinsiyete göre anlamlı bir farklılık göstermekte midir?

$\checkmark$ İngilizce öğretmeni adaylarının FATİH Projesine ve projenin getirdiği teknolojilerin kullanımına yönelik öz-yeterliklerine ilişkin görüşleri nelerdir?

$\checkmark$ İngilizce Öğretmenliği programında yer alan eğitim teknolojilerinin kullanımıyla ilgili derslerin içerikleri MEB tarafindan belirlenen ilgili alandaki öğretmen yeterliklerini ne ölçüde karşılamaktadır?

\section{YÖNTEM}

\subsection{Araştırma Deseni}

Araştırmanın deseni nitel ve nicel verilerin karşılaştırılması ve ilişkilendirilmesi söz konusu olduğundan karma araştırma desenlerinden Eşzamanlı Desen olarak ifade edilebilir (Creswell, 2012).

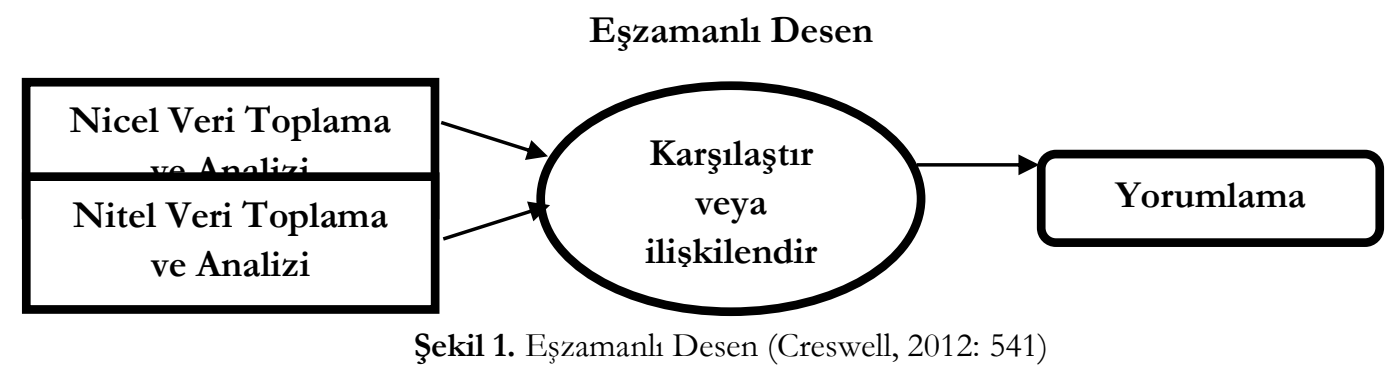

\section{2. Çalışma Grubu}

Araştırmanın çalş̧ma grubunu 2015-2016 Güz Döneminde Akdeniz Üniversitesi, Eğitim Fakültesi, İngilizce Öğretmenliği bölümünde öğrenim gören lisans öğrencileri oluşturmaktadır. Araştırma sürecinde çeşitli nicel ve nitel veri toplama araçlarıyla toplamda 296 kişiden veri toplanmıştır. Çalışma grubunda yer alan gönüllü 296 öğretmen adayı içerisinden 24’ü amaçlı̈ örnekleme yöntemlerinden Maksimum Çeşitlilik Örneklemesi tekniğiyle görüşme yapma amacıyla seçilmiştir.

\subsection{Veri Toplama Araçları}

Çalışmada kullanılacak veriler çeşitli yöntemlerle toplanmıştır. Araştırmadaki nicel verileri toplamak için Kocaoğlu ve Akgün (2013) tarafindan geliştirilen “FATïH Projesi Teknolojileri Öz-Yeterlik Ölçeğ ’” kullanılmıştır. Araştırmada kullanılan 5'li likert tipindeki 40 maddelik ölçeğin geçerlik ve güvenirlik çalısması hazırlayan araştırmacılar tarafindan yapılmıştır. Araştırmacılar bu bağlamda ölçek geliştirme süreçlerinde faktör analizi yaptıktan sonra toplam varyansın \%62'sini açıklayan tek faktörlü bir ölçek ortaya çıkarmışlardır. Araştırmacılar tarafindan belirlenen Cronbach's Alpha güvenirlik katsayısı ,98'dir. Yine de ölçek ile toplanan veriler aracılığıyla güvenirlik analizi tekrar yapılmış ve analizler sonucunda ölçeğin Cronbach's Alpha güvenirlik katsayısı ,97 bulunmuştur. Bu değer Cronbach’s Alpha değerinin yüksek düzeyde olduğunu göstermektedir.

Araştırmadaki nitel verileri toplamak için doküman incelemesi ve görüşme tekniği kullanılmıştır. Bu bağlamda 12 sorudan oluşan yarı yapılandırılmış görüş̧me formları oluşturulmuştur. Görüşme formlarından elde edilecek tüm verileri güvenilir ve geçerli bir analizden geçirilmesi için tema ve kodların oluşturulması süreçlerinde ön analiz çalışmaları yapılmış ve bu analizler nitel araştırma ve ölçme ve değerlendirme alanlarından uzman kişilerce kontrol edilmiştir. Görüşme verilerinin geçerlik ve güvenirliğini săglamak amacıyla katılımcı teyidine de başvurulmuştur.

Doküman incelemesi yapilırken hangi ders içeriklerinin ve hangi öğretmen yeterliklerinin FATİH Projesi bağlamında incelenebileceği konusunda bir program geliştirme uzmanının görüşlerine başvurulmuştur. Araştırmayla ilgili literatürden öğrenmen yeterliklerini inceleyen çalışmalarda hangi derslerin eğitim teknolojilerinin kullanımına yönelik yeterliklerle ilgili olduğunun tespiti için yararlanılmıştır.

\subsection{Verilerin Toplanması}

Araştırmada kullanılan FATIHH Projesi Teknolojileri Öz-Yeterlik Ölçeği kullanılmadan önce ölçeği geliştiren araştırmacılardan e-posta yoluyla izin alınmıştır. Ölçek aracıllğı ile veri toplama sürecinde her bir grupta 
öğrenci sayılarının birbirine yakın olmasına dikkat edilmiştir. Bu bağlamda 163 kadın, 133 erkek ve 67 1. Sınıf, 65 2. Sinıf, 89 3. Sinıf ve 75 4. Sinıf öğrencisinden ölçek aracılı̆̆ılyla veri toplanmıştır.

Doküman incelemesi tekniğinde İngilizce Öğretmenliği programında yer alan ve içerikleri YÖK tarafindan belirlenen derslerden hangilerinin FATİH Projesi kapsamında internet ve bilgisayar teknolojilerinin kullanımına yönelik yeterlikleri kazandırmasının mümkün olabileceği literatürdeki çalışmalardan Çakmak ve Civelek (2013); Uslu (2013), uzman görüşlerinden faydalanılarak ve doğrudan ders içeriklerinin incelenmesiyle belirlenmiştir. Böylelikle veri toplama sürecinde İngilizce Öğretmenliği programlarında var olan 11 ders dikkate alınmıştır. Ayrıca MEB Öğretmen Yetiştirme ve Geliştirme Genel Müdürlüğü tarafindan hazırlanan Hizmetiçi Eğitim Etkinlik Programı ve MEB tarafindan belirlenen İngilizce Öğretmenliği Özel Alan Yeterlikleri ölçüt olarak alınarak tekrarlardan da kaçınmak için İngilizce Öğretmenlerinin FATİH Projesi teknolojilerinin kullanımına yönelik sahip olmaları gereken yeterlikler yeniden düzenlenmiş ve 14 maddelik yeni bir yeterlik listesi oluşturulmuştur (MEB, 2008; 2015) (Bakınız Tablo:7).

Araştırmada kullanılan bir diğer teknik olan yarı yapılandırılmış görüşme formaları bilimsel etik çerçevesinde elde edilen bilgilerin sadece bilimsel nitelik taşıyan bulgular olarak herhangi bir kişisel bilgi verilmeden çalışmada paylaşılacağı İngilizce Öğretmenliği lisans programından seçilen 24 öğrenciye bildirilerek uygulanmış ve daha sonra çözümlenmek üzere ses kaydı yapılmıştır. Yapılan görüşmeler doyum noktasına ulaşıldığı fikri oluştuğu anda bırakılmıştır.

\subsection{Verilerin Analizi}

\subsubsection{FATİH Projesi Teknolojileri Öz-Yeterlik Ölçeği Verilerinin Analizi}

Araştırmada ölçek verilerinin analizi için IBM SPSS Statistics 21 uygulaması kullanılmıştır. Veriler yazılıma girilirken 12 adet ölçek verisi grup, cinsiyet ve çok sayıda maddeye cevap verilmemesi gibi eksik bilgilerden dolayı elenmiştir. Geriye kalan 284 veri ise analiz edilmeden önce IBM SPSS Statistics 21 uygulamasında "Boxplot” tekniği ile uç değer taraması yapılmış ve 8 adet veri uç değer olduğu için veri setinden çıkarılmıştır. Geriye kalan 276 veri analiz için uygun bulunmuştur. Verilerin analizi yapılırken öncelikle normal dağılım gösterip göstermediği Skewness ve Kurtosis (Çarpıklık ve Basıklık) katsayılarına bakılarak tespit edilmiştir. Bu bağlamda toplanan verilerin Skewness değerinin -,35 ve Kurtosis değerinin -,45 olduğu belirlenmiştir. Bu durum değerler +1 ve -1 arasında olduğu için puanların normal dağılımdan önemli bir sapma göstermediğini ifade etmektedir (Büyüköztürk, 2014).

Araştırmada ölçekten alınan puanlara düşük puandan yüksek puana doğru Tablo 1'deki gibi puan aralıkları belirlenmiştir. Belirlenen puan aralıkları dikkate alınarak İngilizce öğretmeni adaylarının öz-yeterlik inanç düzeyleri tespit edilmiştir. Elde edilen puanlar betimsel istatistikler bazında değerlendirilmiştir.

Tablo 1. FATİH Projesi Teknolojileri Öz-Yeterlik Ölçeği Puan Aralıkları ve İnanç Düzeyleri

\begin{tabular}{cc}
\hline Puan Aralığ́ & İnanç Düzeyi \\
\hline $1,00-1,79$ & Çok Düşük \\
$1,80-2,59$ & Düşük \\
$2,60-3,39$ & Orta \\
$3,40-4,19$ & Yüksek \\
$4,20-5,00$ & Çok Yüksek \\
\hline
\end{tabular}

Ölçekten elde edilen veriler normalliği sağladığı için İngilizce öğretmeni adaylarının sınıf değişkenine yönelik öz-yeterlik inançlarında anlamlı bir fark olup olmadığı parametrik testlerden olan İlişkisiz Örneklemler İ̧in Tek Faktörlü V aryans Analiži (One-Way ANOVA) ile, cinsiyet değişkenine yönelik öz-yeterlik inançlarında anlamlı bir fark olup olmadığı ise İlişkisiz. Ömeklemler İ̧̧in T Testi ile belirlenmiştir. Ayrıca ortalama puanların karşılaştırılmasında etki büyüklüğünden de yararlanılmıştır. Bu bağlamda eta kare $\left(\mathrm{\eta}^{2}\right)$ ve Cohen (d) değerleri hesaplanmıştır.

\subsubsection{Görüşme Verilerinin Analizi}

Görüşme verilerin analizi NVivo 9 uygulaması ile yapılmıştır. Görüşme formları ile toplanan verilerin analizinden önce yapılan ses kayıtları dikkatle dinlenerek metne aktarılmıştır. Bu görüşmeler yazıya aktarılmadan önce görüşme yapılan bireylerin bilimsel etik dâhilinde kimliklerinin gizli tutulması için her bir görüşmeci gerçek isminin yerine verilen harf kodları ile yeniden adlandırılmışır. Görüşme metinleri NVivo 9 
uygulamasına aktarılmış ve programa aktarılan bu metinler incelenerek kodlar oluşturulmuş ve bu kodlar temalara dökülmüştür. Bu temalar İngilizce öğretmeni adaylarının:

$\checkmark$ FATİH Projesi hakkındaki genel bilgi birikimlerine yönelik görüşleri,

$\checkmark$ FATIH Projesi teknolojilerini kullanma yeterliklerine yönelik görüşleri,

Eğitim fakültelerindeki FATİH Projesine yönelik eğitim altyapısının durumu hakkındaki görüşleridir.

\subsubsection{Doküman İncelemesi Verilerinin Analizi}

Veriler "Var veya Yok" tekniği ile analiz edilerek "Sayısallaştırma" yoluyla ortaya koyulmuştur. Dokümanlardaki veriler "Sayısallaştırma" yoluyla nicelleştirilirken, "Var veya yok" tekniğinde ilgili kategori incelenen dokumanda varsa “1” yoksa “0” değeri verilebilir (Yıldırım ve Şimşek, 2013). Bu eşleştirme ile YÖK tarafından İngilizce Öğretmenliği programına konulan eğitim teknolojilerinin kullanımına yönelik yeterlikleri geliştirmeyi amaçlayan derslerin içeriklerinin MEB tarafından belirlenen FATİH Projesi teknolojilerinin kullanımına yönelik öğretmen yeterliklerini ne ölçüde karşıladığı tespit edilmeye çalışılmıştır.

\section{BULGULAR}

\section{1. Öğretmen Adaylarını FATİH Projesine Yönelik Öz-yeterlik İnançları}

Araştırmada kullanılan 40 maddeli 5'li likert tipi FATIH Projesi Teknolojileri Öz-Yeterlik Ölçeği incelendiğinde ölçekten alınabilecek en düşük puanın 40, en yükssek puanın ise 200 olduğu görülmektedir. Bu bağlamda araştırmaya katılan çalışma grubunu ölçekten aldığı puanlar Tablo 2'de verilmiştir.

Tablo 2. Çalışma Grubunun FATİH Projesi Teknolojilerine Yönelik Öz-Yeterlik İnanç Puanları

\begin{tabular}{lccccc} 
& $\mathbf{N}$ & En Düşük Puan & En Yüksek Puan & $\bar{X}$ & Ss \\
\cline { 2 - 6 } & 276 & 79 & 196 & 151,21 & 26,23 \\
Önanç Puanları & & & & &
\end{tabular}

Tablo 2 incelendiğinde ölçeğin uygulandığı 276 katılımcının FATİH Projesi teknolojilerini kullanmaya yönelik öz-yeterlik inanç puanlarının ortalamasının 151,21 olduğu görülmektedir. Bu değer 5 üzerinden puanlamada $(\overline{\mathrm{X}}=3,78)$ 'e karşılık gelmektedir. Alınan bu puan 3,40 - 4,19 arası puanlamada ise "Yüksek" inanç düzeyini ifade etmektedir. Bu bilgilere dayanarak çalışma grubunda yer alan bireylerin FATİH Projesi teknolojilerini kullanmaya yönelik öz-yeterlik inançlarının yüksek düzeyde olduğunu söylenebilir.

Ölçekte yer alan 40 maddeden ayrışan 5 madde tek tek incelendiğinde büyük çoğunluğun “Orta” düzeyde cevap verdiği maddelerin "Akıllı tahtaları kullanma konusunda eğitim verebilirim.”, "Akıllı tahta programında (Starboard) çizim yapabilirim.", “Ak1llı tahtalarda simülasyon (benzetim) kullanabilirim." ve "Ak1llı tahta programını (Starboard) kullanarak kendi dokümanlarımla (resim, video vb.) bir ders paketi (.yar uzantılı) hazırlayabilirim.” maddelerinin olduğu görülmüştür. Ayrıca katılımcıların “Çok Yülssek” puan aralığında cevap verdikleri tek maddenin “İnterneti güvenli bir biçimde kullanacak kadar bilgiliyim.” maddesidir.

\subsubsection{Sınıf Değişkenine İlişkin Bulgular ve Yorumlar}

Tablo 3. İngilizce Öğretmeni Adaylarının Sınıf Değişkenine Göre FATİH Projesi Teknolojilerine Yönelik Öz-Yeterlik İnanç Puanları

\begin{tabular}{cccccc}
\hline Sinıflar & N & $\begin{array}{c}\text { En Düşük } \\
\text { Puan }\end{array}$ & $\begin{array}{c}\text { En Yüksek } \\
\text { Puan }\end{array}$ & $\bar{X}$ & ss \\
\hline 1. Sinıf & 62 & 99,00 & 196,00 & 150,46 & 26,18 \\
2. Sinıf & 53 & 117,00 & 194,00 & 156,86 & 21,31 \\
3. Sinıf & 88 & 80,00 & 194,00 & 149,53 & 26,86 \\
4. Sinıf & 73 & 79,00 & 194,00 & 149,75 & 28,59 \\
\hline
\end{tabular}

Tablo 3'te yer alan ölçek verileri incelendiğinde alınan puanların çeşitli farklılaşmalar gösterdiği görülmektedir. Özellikle ortalama puanlar incelendiğinde 1. ve 2. sınıf öğrencilerinin puanlarının 3. ve 4. sınıf öğrencilerinin puanlarına kıyasla az da olsa daha yüksek olduğu görülmektedir. Bu farklılaşmaların anlamlı olup olmadı̆̆ı Tablo 4'de Tek Faktörlü Varyans Analizi (ANOVA) ile incelenmiştir.

Tablo 4. İngilizce Öğretmeni Adaylarının FATİH Projesi Teknolojilerini Kullanmaya Yönelik Öz-yeterlik İnanç Düzeylerinin Sınıfa Göre Farklılaşma Durumu ile İlgili Tek Faktörlü Varyans Analizi (ANOVA) Sonuçları

\begin{tabular}{lrrrrr}
\hline $\begin{array}{l}\text { Varyansın } \\
\text { Kaynağ1 }\end{array}$ & $\begin{array}{r}\text { Kareler } \\
\text { Toplamı }\end{array}$ & df & $\begin{array}{r}\text { Kareler } \\
\text { Ortalamas1 }\end{array}$ & $\mathbf{f}$ & p \\
\hline Gruplararas1 & 2132,841 & 3 & 710,947 & 1,034 &, 378 \\
Gruplariçi & 187104,970 & 272 & 687,886 & & \\
Toplam & 189237,812 & 275 & & & \\
\hline
\end{tabular}


Tablo 4'deki analiz sonuçları, İngilizce öğretmeni adaylarının FATİH Projesi kapsamında internet ve bilgisayar teknolojilerini kullanmaya yönelik öz-yeterlik inanç düzeyleri arasında sınıf bakımından anlamlı bir fark olmadığını göstermektedir, $F(3,272)=1,03$, p >.01. Başka bir deyişle İngilizce öğretmeni adaylarının FATİH Projesi teknolojilerine yönelik öz-yeterlik inançları öğrenim görülen sınıfa bağlı olarak anlamlı bir şekilde değişmemektedir.

\subsubsection{Cinsiyet Değişkenine İlişkin Bulgular ve Yorumlar}

Tablo 5. İngilizce Öğretmeni Adaylarının Cinsiyet Değișkenine Göre FATİH Projesi Teknolojilerine Yönelik ÖzYeterlik İnanç Puanları

\begin{tabular}{cccccc}
\hline Cinsiyet & N & En Düşük Puan & En Yüksek Puan & $\bar{X}$ & ss \\
\hline Kadın & 158 & 79,00 & 195,00 & 145,80 & 25,66 \\
Erkek & 118 & 103,00 & 196,00 & 158,44 & 25,32 \\
\hline
\end{tabular}

Tablo 5’teki ölçekten alınan puanlar cinsiyet değişkenine göre incelendiğinde kadın ve erkek katılımcıların puanları arasında erkekler lehine farklılaşmaların olduğu görülmektedir. Bu farklılaşmaların anlamlı olup olmadığı Tablo 6'da İlişkisiz Örneklemler İçin T Testi ile incelenmiştir.

Tablo 6. İngilizce Öğretmeni Adaylarının FATİH Projesi Teknolojilerini Kullanmaya Yönelik Öz-yeterlik İnanç Düzeylerinin Cinsiyete Göre Farklılaşma Durumu ile İlgili İlişkisiz Örneklemler İçin T Testi Sonuçları

\begin{tabular}{|c|c|c|c|c|c|c|}
\hline $\begin{array}{c}\text { Değişken } \\
\text { Cinsiyet }\end{array}$ & $\mathrm{n}$ & $\bar{X}$ & ss & $\mathrm{t}$ & df & $\mathrm{p}$ \\
\hline Kadin & 158 & 145,80 & 25,66 & 4,07 & 274 & ,000 \\
\hline Erkek & 118 & 158,44 & 25,32 & & & \\
\hline
\end{tabular}

Tablo 6'da yer alan analiz sonuçlarına göre İngilizce öğretmeni adaylarının FATİH Projesi teknolojilerini kullanmaya yönelik öz-yeterlik inançları cinsiyete göre anlamlı bir farkll1ı göstermektedir, t(274)=4,07, p<.01. Erkek katılımcıların öz-yeterlik inançları $\left(X^{-}=158,44\right)$ kadın katılımcılara göre $\left(X^{-}=145,80\right)$ daha yüksektir.

Cinsiyet değişkenine göre yapılan analizlerde anlamlı farklılık olduğu için eta kare $\left(\mathrm{n}^{2}\right)$ ve Cohen (d) değerleri yani etki büyüklüğü hesaplanmıştır. Bu bağlamda hesaplanan $\eta^{2}$ değeri .056'dır. Buna göre öz-yeterlik ölçeği puanlanında gözlenen varyansın yaklaşık \%6'sının cinsiyete bağlı olduğu söylenebilir. Bir başka deyişle bağımsız değişken (cinsiyet), bağımlı değişken (FATİH Projesi teknolojilerini kullanmaya yönelik öz-yeterlik inanc1) üzerinde orta düzeyde etki büyüklüğüne sahiptir. Ayrıca hesaplanan Cohen (d) değeri .49'dur. Bu sonuç kadın ve erkek öğretmen adaylarının FATIHH Projesi Teknolojileri Öz-Yeterlik Ölçeği ortalama puanları arasındaki farkın .49 standart sapma kadar olduğunu gösterir. Yani Cohen (d) değerine göre de etki büyüklüğü .5 (orta) düzeye yakındır.

\section{2. İngilizce Öğretmeni Adaylarının FATİH Projesine İlişkin Görüşleri}

\subsection{1. İngilizce Öğretmeni Adaylarının FATİH Projesi Hakkındaki Genel Bilgi Birikimlerine}

\section{Yönelik Görüşleri}

Görüşmeler sırasında öğretmen adaylarının FATİH Projesi hakkında genel düşünceleri ve bu konudaki bilgi birikimlerinin durumu irdelenmiştir. Bu bağlamda görüşmecilerin FATïH Projesi hakkındaki genel bilgi birikimleri, projeye yönelik sahip olunan bilgi birikiminin kaynakları, proje hakkındaki genel düşünceleri ve proje donanım ve yazılım altyapısı hakkındaki düşünceleri ile ilgili bilgiler alınmıştır.

Görüşmelerde öğretmen adaylarının 22'si genel ifadeler kullanarak FATİH Projesinin eğitimde teknoloji kullanımına yönelik bir proje olduğunu ifade etmişlerdir.

"Sanırım okullarda internet erişiminin sağlanması, tablet uygulamalarının getirilmesiyle ilgili bir şey.

Son yıl biz de kullandık lise döneminde.” (L)

"Yani çok kısa bir bilgim var. Böyle teknolojik iyileştirmeler yaptıklarını biliyorum okullarda." (H)

Görüşmecilerin FATİH Projesi hakkında sahip oldukları belli ölçüdeki bilgi birikiminin kaynağı sorgulanmıstır. Bu bağlamda 8 görüşmeci mezun olunan lise, 7 görüşmeci medya (haberler, sosyal medya vb.), 4 görüşmeci arkadaş çevresi ve 3 görüşmeci kişisel merak cevaplarını vermişlerdir.

"Lisede akıllı tahtada, yani tam olarak orada öğrendim. Başka bir yerde duymamıştım.” (V) 
"Sınıfımda birkaç arkadaşım sanırım bu tablet dağıtılması vs. ile alakalı konuşuyorlardı da o şekilde duydum. Ayrıntısını da çok bilmiyorum.” (G)

"Ben internetten duydum tabi ki bunların büyük çoğunluğunu. Zaten ilk başlarda böyle bir şey ortaya çıktığında ilk duyduğumuz yer televizyonlar, haberler oldu. Daha sonra hepimiz sosyal medyadayız zaten her gün.” (T)

Görüşme yapılan öğretmen adaylarının 20 katılımcı gibi büyük bir çoğunluğu FATİH Projesi hakkında olumlu düşünceler ortaya koymuşlardır.

"Proje bence çok güzel bir proje. Çünkü başladığı zaman teknoloji uygun bir şekilde kullanılırsa daha hızlı bir şekilde verim alınabilir diye düşünüyorum.” (X)

“Aslında çok güzel bir sistem. Yani yararlı kullanılabilirse, yaygınlaştırılabilirse güzel bir sistem.

Yararlı olur öğrenciler için.” (S)

Yapılan görüşmeler İngilizce öğretmeni adaylarının FATİH Projesi hakkında gerek genel bilgi birikimleri olsun gerekse özelde donanım ve yazılım altyapısı hakkında üst seviyede olmasa da belirli bir düzeyde bilgilerinin olduğunu göstermektedir. Her ne kadar öğretmen adayları proje hakkında çok detaylı bilgiye sahip olmasalar da eğitimde teknolojik altyapının varlığı hakkında olumlu görüşler ortaya koymuşlardır.

\subsection{2. İngilizce Öğretmeni Adaylarının FATİH Projesi Teknolojilerini Kullanma Öz-}

\section{Yeterliklerine Yönelik Görüşleri}

Görüşme yapılan öğretmen adaylarının FATİH Projesi ile ilgili sahip oldukları yeterlikler görüşmelere konu olmuştur. Öğretmen adaylarının 15’i farklı ortamlarda projenin uygulandığ1 okullarda da yer alan donanım ve yazılımları kullanma deneyimine sahip olduklarını veya teknolojiye duydukları ilgiden dolayı kısmen bu donanım ve yazılımları kullanmaya yönelik önbilgilerinin olduğunu ifade etmişlerdir. Fakat sahip oldukları bu yeterliklerin özellikle kendi ilgilerinden kaynaklandığını vurgulamışlardır. Ayrıca yazılımlardan bahsederken projenin temel içerik sağlayıcısı EBA'dan bahsedilmemiş, genel ifadeler kullanılmıştır.

"Ben daha önce belki bir yerde çalıştı̆̆ım için söyledim. Bir yerde çalıştım, orada da öğretildi onlar bana kısaca. O yüzden donanımlı olduğumu düşünüyorum o konuda.” (N)

“Açıkçası benim teknolojiyle aram iyidir ve ben bu teknolojileri gayet iyi kullanabileceğimi düşünüyorum. Fakat bu benim şahsi özelliğim. Çükü ben teknolojiye biraz merakliyım.” (J)

Diğer görüşmeciler ise projenin uygulama süreçlerinde kendilerini yeterli görmediklerini fakat kendilerine projenin getirdiği teknolojilerin kullanımıyla ilgili eğitim verilmesi durumunda başarılı olabileceklerine ve bu konuda istekli olduklarına, aksi takdirde ileride bu konuda sıkıntılar yaşayabileceklerine dikkat çekmişlerdir.

"Hayır, yeterli görmüyorum çünkü bununla ilgili bir eğitim almadım. Şu anda okuduğum okulda da

herhangi bir eğitim verilmiyor bu konuda. Eğer ileride kullanmamız gerekiyorsa bence şu an bir eğitim verilmeli. Çünkü sonradan öğretmen olduğumuzda zorlanırız.” (O)

"Şu an fazla yeterli görmüyorum çünkü dediğim gibi bilmediğim için fakat eğer bana öğretilirse bunu en iyi şekilde değerlendirmek isterim.” (Z)

İngilizce öğretmeni adaylarının büyük bir kısmı gerek FATİH Projesi ile ilgili genel yeterlikler gerekse projenin donanım ve yazılım altyapısını kullanmaya yönelik yeterlikler konusunda kendilerini belli ölçüde yeterli görmektedir. Bu konuda kendini yetersiz gören kesim ise öğrenmeye kapalı değildir. Ayrıca görüşmeciler projenin getirdiği teknolojilerle ilgili aşinalığın ve bu konuda sahip olunan yeterliklerin üniversite tarafından değil de öğretmen adaylarının kendi tecrübelerinden kaynaklandığını vurgulamışlardır.

\subsection{3. İngilizce Öğretmeni Adaylarının Eğitim Fakültelerindeki FATİH Projesine Yönelik Eğitim} Altyapısının Durumu Hakkındaki Görüşleri

Görüşmeler sırasında İngilizce öğretmeni adaylarının İngilizce Öğretmenliği programındaki derslerin FATİH Projesi yeterliklerini kazandırma durumu, üniversitede eğitim teknolojilerinin kullanımı adına yapılanlar ve eğitim alınan ortamın projeye yönelik yeterlikleri kazandırmadaki elverişlilik durumu hakkındaki görüşleri de irdelenmiştir.

Yapılan görüşmelerde İngilizce Öğretmenliği programındaki derslerin projenin yeterliklerini kazandırma durumu ile ilgili görüşmecilerin 19 katılımcı gibi büyük bir çoğunluğu üniversite ortamında projeyle ilgili 
neredeyse hiçbir uygulama görmediklerini ve aldıkları derslerin bu konuda hiçbir şey kazandırmadığını belirtmiştir.

"Bu okulda FATİH Projesiyle ilgili bir şey var mı? O yüzden pek bağlantı kuramadım.” (U)

"Şimdi ben bu okuldayım fakat projeyle ilgili bir şey yapıldığını görmedim. Derslerimizde sadece ders işliyoruz, FATİH Projesiyle ilgili bir şey duymadım.” (Z)

Geriye kalan görüşmeciler ise bu konuda herhangi bir görüş belirtmemiştir.

Yapılan görüşmelerde öğretmen adayları üniversite eğitiminin FATİH Projesi teknolojilerinin kullanımı adına kendilerine bir şey kazandırmadığını vurgulasalar da bu bağlamda eğitim alınan ortamın projeye yönelik yeterlikleri kazandırmadaki elverişlilik durumu hakkında da çeşitli görüşlere sahiptir. Öğretmen adaylarının 17'si eğitim aldıkları fakültenin FATİH Projesi teknolojilerine yönelik yeterlikleri kazandıracak elverişliliğe sahip olduğunu, bu bağlamda eğitim verebilecek nitelikli hocaların olduğunu ve gerekli donanım altyapısının da var olduğunu düşünmektedir.

“Aslında sahip ama öğretilmiyor işte öyle bir şey var. Donanım duruyor ama duruyor. Yani bize gidip de böyle böyle bir proje var. Okulda böyle gidip kullanacaksınız diye çok da fazla eğitim verilmedi.” (B)

"Aslında verilebilir, bu alanda kendini geliştirmiş insanlar mutlaka var. Bunlar gelip bize eğitim verebilir, bunlara biz katılabiliriz. Tek sorun sinıftaki mevcudun kalabalık olmasından kaynaklanabilir." (T)

Bu konuyla ilgili 1 görüşmeci fakülte şartlarının FATİH Projesi ile ilgili öğretmen yeterliklerini kazandırma konusunda elverişli olmadığına ilişkin görüş bildirirken, geriye kalan görüşmeciler bu konuda herhangi bir görüş ifade etmemiştir.

\subsection{Ders İçeriklerinin FATİH Projesine İlişkin Öğretmen Yeterliklerini Karşılama Durumu}

Bu bölümde MEB Öğretmen Yetiştirme ve Geliştirme Genel Müdürlüğü tarafından hazırlanan Hizmetiçi Eğitim Etkinlik Programı'nda yer alan FATİH Projesine yönelik öğretmen yeterlikleri ve İngilizce Öğretmenliği Özel Alan Yeterlikleri ile YÖK tarafindan 2007'de hazırlanan Eğitim Fakültesi Öğretmen Yetiştirme Lisans Programlarında yer alan İngilizce Öğretmenliği lisans programına ait derslerin kazanımları içerisinden seçilen eğitimde bilgi ve iletişim teknolojilerinin kullanımına yönelik kazanımlar karşılaştırılmıştır. "Var veya yok" tekniğine göre derslerin ve öğretmen yeterliklerinin karşılaştırması ve hangi derslerin hangi öğretmen yeterliğini kazandırabileceği Tablo 7'de, sözü edilen derslerin öğretmen yeterliklerini karşlama durumu Şekil 2'de verilmiştir.

Tablo 7."Var veya yok” Tekniğine Göre Derslerin ve Öğretmen Yeterliklerinin Karșılaştırması

\begin{tabular}{|c|c|c|c|c|c|c|c|c|c|c|c|c|}
\hline$\frac{\overrightarrow{ \pm}}{\frac{\pi}{0}}$ & 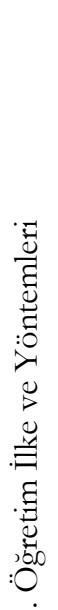 & 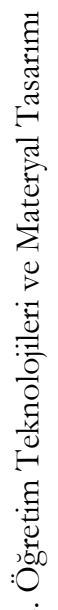 & 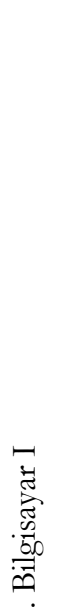 & 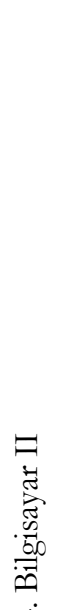 & 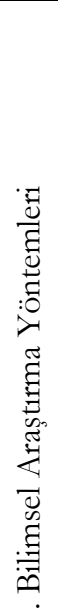 & 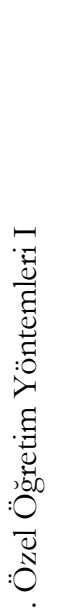 & 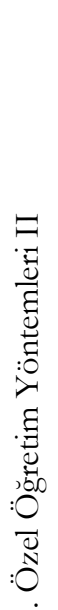 & 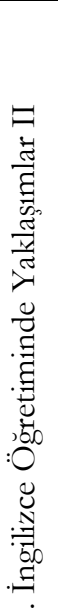 & 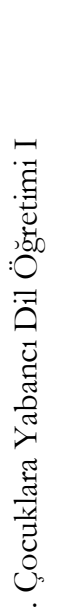 & 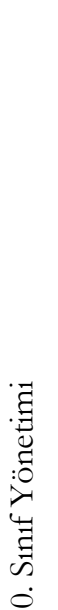 & 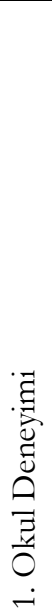 & $\frac{\sqrt{\pi}}{\frac{\pi}{2}}$ \\
\hline Öğretmen Yeterlikleri & $\dot{-}$ & i & $\dot{r}$ & $\dot{+}$ & $\dot{10}$ & $\dot{0}$ & $\dot{\sim}$ & $\infty$ & $a^{\circ}$ & $\stackrel{\wp}{=}$ & $\exists$ & \\
\hline $\begin{array}{l}\text { 1. Eğitimde teknoloji kullanımıyla ilgili temel } \\
\text { kavramları bilir, }\end{array}$ & 0 & 1 & 1 & 1 & 0 & 0 & 0 & 0 & 0 & 0 & 0 & 3 \\
\hline $\begin{array}{l}\text { 2. Eğitimde FATİH Projesinin amacını, kapsamını ve } \\
\text { beklentilerini bilir, }\end{array}$ & 0 & 0 & 0 & 0 & 0 & 0 & 0 & 0 & 0 & 0 & 0 & 0 \\
\hline $\begin{array}{l}\text { 3. Proje kapsamında sağlanan BT ekipmanlarının } \\
\text { kurulumunu, kullanımını yapar ve karşılaşılan temel } \\
\text { problemleri çözer, }\end{array}$ & 0 & 1 & 0 & 0 & 0 & 0 & 0 & 0 & 0 & 0 & 0 & 1 \\
\hline $\begin{array}{l}\text { 4. Dil öğretiminde kullanılan yazılımları ve internet } \\
\text { kaynaklarını izler, }\end{array}$ & 0 & 1 & 1 & 0 & 0 & 0 & 0 & 1 & 0 & 0 & 0 & 3 \\
\hline
\end{tabular}


5. LCD Panel Etkileșimli tahta yazılımını kullanmayı bilir,

6. EBA ve İnternet üzerinde yayımlanan, ders etkinliklerinde kullanabileceği materyalleri arar, bulur ve telif haklarına uygun olarak seçer,

7. Öğrenmenin daha etkin gerçekleșmesi için teknolojik kaynaklardan yararlanır ve öğrencileri bu kaynaklara erişim için teşvik eder,

8. Öğrencilerin teknolojik kaynaklardan yararlanabilmeleri için uygun ortamlar hazırlayarak bu kaynaklara eşit olarak erişimlerini sağlar,

9. Öğrencilerin İngilizce öğreniminde ihtiyaç duydukları teknolojik kaynakları eleştirel gözle değerlendirerek etkin kullanmalarını sağlar,

10. Öğrencilerin günlük yaşamlarıyla ilişkili, dil gelişim düzeylerine ve öğrenme sitillerine uygun yazılı, görsel ve işitsel materyalleri kullanır,

11. İhtiyaç duyduğu konularda özgün materyal tasarlar ve seçilen materyal üzerinde değişiklik yapar,

12. İngilizce öğretiminde dinleme, okuma ve yazma etkinliklerinde öğrenci ilgi ve ihtiyaçlarına göre çeşitli kaynak ve materyallerden yararlanır,

13. Bulunan/değiștirilen/tasarlanan materyali etkili kullanmak üzere bir ders planı hazırlar ve plana uygun olarak sunar,

14. Kullandığı materyalleri kullanıșlılığı, güncelliği, etkililiği ve verimliliği gibi açllardan değerlendirerek zenginleştirir.

\begin{tabular}{llllllllllllllll}
\hline Toplam & 1 & 12 & 3 & 4 & 0 & 1 & 3 & 2 & 4 & 1 & 2
\end{tabular}

Şekil 2. Derslerin Öğretmen Yeterliklerini Karşılama Durumu

Tablo 7 ve Şekil 2 incelendiğinde YÖK tarafından İngilizce Öğretmenliği Lisans Programında belirlenen derslerin ve bu derslerin içeriklerinin MEB’in İngilizce Öğretmenlerinden beklediği FATİH Projesi teknolojilerinin kullanımına yönelik yeterliklerin 14’ünden 13’ünü karşılamaya olanak tanıdığı görülmektedir. Bu durum yüzdelik ifade ile \%92,85’e karşllık gelmektedir. Bir başka deyişle İngilizce Ö̆ğretmenliği programında yer alan ve araştırmada incelenen 10 ders her ne kadar FATİH Projesi ile ilgili doğrudan içeriklere sahip değilse de projenin gerektirdiği eğitim teknolojilerine yönelik yeterlikleri kazandırabilecek esnekliğe sahiptir. Fakat analizler sırasında literatürde yer alan ve öğretmen adaylarına eğitim teknolojilerinin kullanımına yönelik çeşitli yeterlikleri kazandırdığı ifade edilen "Bilimsel Araştırma Yöntemler" dersinin FATİH Projesi teknolojilerinin kullanımına yönelik herhangi bir yeterliği kazandıracak içeriğe sahip olmadığı görülmüştür. 


\section{SONUÇ, TARTIŞMA VE ÖNERİLER}

\subsection{Sonuç ve Tartışma}

Araştırmanın sonuçları ve bunlarla ilgili tartışma veya yorumlar maddeler halinde şöyledir:

$\checkmark$ Çalışma grubunda yer alan katılımcıların FATİH Projesi teknolojilerini kullanmaya yönelik öz-yeterlik inançları yüksektir. Kutluca ve Ekici (2013); Palabıyık (2013) Öğretmen adayları üzerinde yaptıkları çalışmalarda benzer bulgular ortaya koymuşlardır. Yapılan görüşmelerden elde edilen bulgular da bu bulguları doğrular niteliktedir. Çünkü görüşmecilerin büyük çoğunluğu temel hatlarıyla da olsa projeden haberdar olduklarını, yarıdan fazlası ise projenin getirmiş olduğu teknolojileri kullanma konusunda kendilerini yeterli gördüklerini ifade etmişlerdir.

$\checkmark \quad$ İngilizce öğretmeni adaylarının FATİH Projesi teknolojilerine yönelik öz-yeterlik inançları öğrenim görülen sınıfa bağlı olarak anlamlı bir şekilde farklııı göstermemektedir. Yılmaz, Gerçek, Köseoğlu ve Soran (2006) çalışmalarında da benzer bir sonuca ulaşmışlardır. Yıllar içerisinde öğrencilerin bu bağlamdaki yeterliklerinin gelişmesi beklenirken sınıf değişkenine göre anlamlı bir farklılaşmanın olmaması üzerinde düşünülmesi gereken bir konudur.

$\checkmark$ İngilizce öğretmeni adaylarının FATİH Projesi teknolojilerine yönelik öz-yeterlik inançları cinsiyete göre anlamlı bir farkl1l1k göstermektedir. İlgili literatür incelendiğinde benzer bulguları görmek mümkündür. Akkoyunlu ve Orhan (2003); Korkut ve Akkoyunlu (2008) öğretmen adayları üzerinde yaptıkları çalışmalarda erkeklerin bilgisayar teknolojilerinin kullanımına yönelik öz-yeterlik inançlarının kadınlara kıyasla daha yüksek olduğunu tespit etmişlerdir.

$\checkmark \quad$ İngilizce öğretmeni adayları FATİH Projesi ve eğitimde teknolojik altyapının varlı̆̆ı hakkında yalnızca genel hatlarıyla bilgi sahibi olsalar da olumlu görüşler ortaya koymuşlardır. Elaziz (2008), İngilizce derslerinde etkileşimli (akıllı) tahta kullanımına yönelik öğrenci ve öğretmen tutumlarına ilişkin çalışmasında öğretmenlerin bu bağlamda olumlu tutumlara sahip olduğunu belirlemiştir. Görüşmecilere göre proje ve projenin getirmiş olduğu etkileşimli (akıllı) tahta, tablet bilgisayar ve internet altyapısı yabanc1 dil eğitiminde gereken görsel ve işitsel materyaller bünyesinde barındırmaktadır. Fakat internet altyapısı ya da yazılımlar konusunda sorulan sorulara EBA ile ilgili cevap alınamamıstır.

$\checkmark$ Ayrıca yapılan doküman incelemesi sonucunda YÖK tarafindan İngilizce Öğretmenliği Lisans Programında belirlenen derslerin ve bu derslerin içeriklerinin MEB’in İngilizce öğretmenlerinden beklediği FATİH Projesi teknolojilerinin kullanımına yönelik yeterlikleri \%92,85 karşılayacak esnekliğe sahip olduğu görülmüştür. Uygun ve Akınc1 (2015)'e göre eğitim fakültesi görev yapan öğretim elemanları YÖK tarafından belirlenen ders içeriklerinin sınıfta hangi konuyu anlatacaklarıyla ilgili kendilerine gerekli esnekliği sağladığı görüşündedir. Fakat yine de projenin sağlıklı bir biçimde yürütülebilmesi için oldukça önemli bir yeterlik olan "Eğitimde FATİH Projesinin amacını, kapsamını ve beklentilerini bilir.” yeterliği İngilizce Öğretmenliği ders ve içeriklerinde yer almamaktadır. Bu durum İngilizce Öğretmenliği Lisans Programının eğitim teknolojilerinin kullanımına yönelik yeterlikleri kazandırmaya olanak tanıdığını fakat programda yer alan derslerde özellikle FATİH Projesi ile ilgili bir içeriğin yer almadığını göstermektedir.

\section{2. Öneriler}

Araştırmanın sonuçlarına ilişkin bazı öneriler şöyledir:

$\checkmark$ Öğretmen adayları FATİH Projesi ile ilgili daha somut ve düzenli bir eğitim almalıdır. Bu bağlamda öğretmen yetiştiren programlara FATİH Projesiyle ilgili bir öğrenme modülü konabilir.

$\checkmark$ Öğretim Teknolojileri ve Materyal Tasarımı dersine FATİH Projesi ile ilgili bir ünite eklenebilir.

$\checkmark$ Eğitim fakültesi ders içerikleri çağın gereklerine göre güncellenebilir ve FATİH Projesinin amac1, kapsamı ve beklentilerine yönelik farkındalı̆̆ı artıracak içerikler eklenebilir.

$\checkmark \quad$ Ingilizce öğretmenliği program yeterlikleri ile ders kazanımları eşleştirilerek genel alan ve özel alan öğretmen yeterliklerine uygun öğretmen adaylarının yetiştirilmesine yönelik program iyileştirme çalışmaları yapılabilir. 
$\checkmark$ Kadın öğretmen adaylarının hem projenin getirdiği teknolojileri kullanma bağlamında hem de genel olarak eğitim teknolojilerinin kullanımı açısından erkek öğretmen adaylarıyla aynı seviyede eğitim almasını sağlayacak tedbirler alınabilir.

$\checkmark$ İngilizce öğretmeni adaylarının genel teknolojik yeterlikleri yüksek olsa da akıllı (etkileşimli) tahta kullanımıyla ilgili üst düzey bilgi gerektiren becerilerin geliştirilmesine yönelik bir eğitim verilebilir.

$\checkmark$ YÖK tarafindan belirlenen ders içeriklerinin Bologna süreci de dikkate alınarak düz bir paragraf yerine kazanımlar şeklinde güncellenmesi hedeflerin öğrenme davranışlarına dönüştürülmesine olanak sağlayabilir.

\section{KAYNAKÇA}

Akkoyunlu, B. ve Orhan, F. (2003). Bilgisayar ve öğretim teknolojileri eğitimi (BÖTE) bölümü öğrencilerinin bilgisayar kullanma öz yeterlik inanc1 ile demografik özellikleri arasındaki ilişki. TOJET: The Turkish Online Journal of Educational Technology, 2(3), 86-93.

Bandura, A. (1977). Self-efficacy: toward a unifying theory of behavioral change. Psychological Review, 84(2), 191215.

Bandura, A. (1982). Self-efficacy mechanism in human agency. American psychologist, 37(2), 122-147.

Bandura, A. (1986). Social foundations of thought and action: A social cognitive theory. Prentice-Hall, Inc.

Bandura, A. (1988). Organisational applications of social cognitive theory. Australian Journal of Management, 13(2), 275-302.

Büyüköztürk, Ş. (2014). Sosyal bilimler için veri analiz̨i el kitabı. (Genişletilmiş 3. Baskı). Ankara: Pegem Akademi Yayıncillk.

Creswell, J. W. (2012). Educational research: planning, conducting, and evaluating quantitative. (4. Bask1). Boston: Pearson Education, Inc.

Çakmak, E. ve Civelek, F. (2013). Sınıf öğretmenliği lisans programının MEB özel alan öğretmen yeterlikleri açısından incelenmesi. Electronic Journal of Social Sciences, 12(47), 349-367.

Duffy, J. L. ve McDonald, J. B. (2011). Teaching and learning with technology. (4. Bask1). Boston: Pearson Education, Inc.

Elaziz, F. (2008). Attitudes of students and teachers towards the use of Interactive whiteboards in EFL classrooms: Yayımlanmamış Yüksek Lisans Tezi, Bilkent Üniversitesi, Ankara.

Friedman, I. A. ve Farber, B. A. (1992). Professional self-concept as a predictor of teacher burnout. The Journal of Educational Research, 86(1), 28-35.

Fuchs, L. S., Fuchs, D. ve Bishop, N. (1992). Instructional adaptation for students at risk. The Journal of Educational Research, 86(2), 70-84.

Kayak, S. ve Kır, E. (2015). Evaluation of candidate language teachers' level of knowledge and ideas towards the use of interactive whiteboard. Journal of Computer and Education Research, 3 (5), 50-77.

Kinzie, M. B. ve Delcourt, M. A. (1991, Nisan). Computer technologies in teacher education: the measurement of attitudes and self-efficacy. Annual Meeting of the American Educational Research Association'da sunulmuştur. Chicago,IL.

Korkut, E. ve Akkoyunlu, B. (2008). Yabancı dil öğretmen adaylarının bilgi ve bilgisayar okuryazarlık özyeterlikleri. Hacettepe Üniversitesi Ë̈itim Fakültesi Dergisi, 34(34), 178-188.

Kutluca, T. ve Ekici, G. (2010). Öğretmen adaylarının bilgisayar destekli eğitime ilişkin tutum ve öz-yeterlik alg1larının incelenmesi. Hacettepe Üniversitesi Eğitim Fakültesi Dergisi, 38(38), 177-188.

MEB, (2008). İngilizce Öğretmeni Özel Alan Yeterlikleri 15 Şubat 2016 tarihinde http://otmg.meb.gov.tr/alaningilizce.html adresinden alınmışır

MEB, (2012). Proje hakkında. 8 Temmuz 2015 tarihinde http://fatihprojesi.meb.gov.tr/tr/icerikincele.php?id=6 adresinden alınmıştır.

MEB, (2015). Geliştirilen ve Güncellenen Standart Kriterlere Uygun olarak hazırlanan Örnek Hizmetiçi

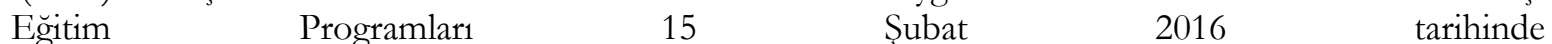
http://hedb.meb.gov.tr/net/ standart program/index.php?dir=Standart + Programlar $\% 2 \mathrm{~F}$ adresinden alınmıştır.

Midgley, C., Feldlaufer, H. ve Eccles, J. S. (1989). Change in teacher efficacy and student self-and task-related beliefs in mathematics during the transition to junior high school. Journal of educational Psychology, 81(2), $247-258$

Pajares, F. (1996). Self-efficacy beliefs in academic settings. Review of educational research, 66(4), 543-578. 
Pajares, F. (1997). Current directions in self-efficacy research. Advances in motivation and acbievement, 10(149), 1 49.

Palabıyık, P.Y. (2013), Hiæmetiçi Ingiližce ögretmenlerinin teknoloji entegrasyonuyla ilgili öz-yeterlilik inamışlar: FATiH projesinden alıntılar. Yayınlanmamış Yüksek Lisans Tezi, Abant İzzet Baysal Üniversitesi Eğitim Bilimleri Enstitüsü, Bolu.

Perkmen, S. ve Tezci, E. (Ed.). (2011). Eğitimde teknoloji entegrasyonu. Ankara: Pegem Akademi Yayınları.

Riggs, I. M. ve Enochs, L. G. (1990). Toward the development of an elementary teacher's science teaching efficacy belief instrument. Science Education, 74(6), 625-637.

Ross, J. A. (1992). Teacher efficacy and the effects of coaching on student achievement. Canadian Journal of Education/Revue canadienne de l'education, 51-65.

Schunk, D. H. ve Zimmerman, B. J. (2007). Influencing children's self-efficacy and self-regulation of reading and writing through modeling. Reading \& Writing Quarterly, 23(1), 7-25.

Soodak, L. C. ve Podell, D. M. (1996). Teacher efficacy: Toward the understanding of a multi-faceted construct. Teaching and Teacher Education, 12(4), 401-411.

Tomakin, E. ve Yeşilyurt, M. (2013). Bilgisayar destekli yabancı dil öğretim çalışmalarının meta analizi: Türkiye örneği. Yǚüncü ynl Üniversitesi Eğitim Fakültesi Deryası, 10(1), 248-263.

Tschannen-Moran, M. ve Hoy, A. W. (2001). Teacher efficacy: Capturing an elusive construct. Teaching and teacher education, 17(7), 783-805.

Tschannen-Moran, M. ve Hoy, A. W. (2007). The differential antecedents of self-efficacy beliefs of novice and experienced teachers. Teaching and teacher Education, 23(6), 944-956.

Uslu, S. (2013). Sosyal bilgiler eğitimi lisans programının sosyal bilgiler öğretmeni özel alan yeterlikleri açısından incelenmesi. International Journal Of Eurasia Social Sciences, 12(4), 126-139.

Uygun, S. ve Akınc1, M. (2015, 22-24 Ekim) Ë̆gitim fakültesi ögretim elemanlarnn ögrrenme-ögretme süreçlerine yönelik. özerklik görüsleri. Uluslararası Eğitim Programları ve Öğretim Kongresi’nde sunulmuştur, Adana: Çukurova Üniversitesi.

Yıldırım, A. ve Şimşek, H. (2013). Sosyal bilimlerde nitel araştırma yöntemleri. (9. Baskı). Ankara: Seçkin Yayıncılık.

Yılmaz, M., Gerçek, C., Köseoğlu, P. ve Soran, H. (2006). Hacettepe Üniversitesi biyoloji öğretmen adaylarının bilgisayarla ilgili öz-yeterlik inançlarının incelenmesi. Hacettepe Üniversitesi Eğitim Fakültesi Dergisi, 30(30), 278-287.

Wang, L., Ertmer, P. A. ve Newby, T. J. (2004). Increasing preservice teachers' self-efficacy beliefs for technology integration. Journal of Research on Technology in Education, 36(3), 231-250.

YÖK, (2007). Ë̆ğtim fakültesi ögretmen yetistirme lisans programlar. Ankara: Yükseköğretim Kurulu Yayını.

\section{Citation Information}

Akıncı, M. (2017). İngilizce Öğretmeni Adaylarının FATİH Projesine Yönelik Öz-Yeterlikleri. Dicle Üniversitesi Ziya Gökalp Eğitim Fakültesi Dergisi, 30, 543-555. 